\title{
A Hermenêutica do Desenvolvimento Nacional à Luz do Estado Democrático de Direito
}

\author{
The Hermeneutics of National Development \\ according to the Democratic State
}

Guilherme Sandoval Góes ${ }^{1}$

Cleyson de Moraes Mello ${ }^{2}$

Resumo: O presente estudo propõe uma nova leitura da Constituição de 1988 sobre a extensão da proteção dos direitos humanos advinda dos sistemas nacional e global. Pretende, pois, analisar como se realiza, à luz do Texto Constitucional de 1988 e da legislação infraconstitucional aplicável, a conexão entre o Direito e a Geopolítica. A questão é saber se existe ou não latitude normativa na Constituição para responder aos desafios trazidos pelo Estado Pós-moderno de Direito.

1 Pós-Doutorando em Geopolítica, Cultura e Direito pela UNIFA. Doutor e Mestre em Direito pela UERJ. Professor Emérito da ECEME. Membro do PPGCA da UNIFA e PPGSID da ESG. Professor de Direito Constitucional da EMERJ, UNESA e UCAM. Diplomado pelo Naval War College dos Estados Unidos da América (Newport, Rhode Island). Chefe da Divisão de Geopolítica e Relações Internacionais da ESG. Membro da Academia Brasileira de Estudos Estratégicos (ABRAEE).

E-mail: guilherme.sandoval@terra.com.br

2 Coordenador do curso de graduação em direito da Faculdade de Direito da UERJ. Professor Adjunto da Faculdade de Direito da UERJ.

E-mail: profcleysonmello@hotmail.com 
Palavras-chave: Geopolítica. Hermenêutica do Desenvolvimento Nacional. Direitos Humanos.

Abstract: This study propose a new reading of Constitucional Law about the extent of human rights protection from the national and global systems. So there is the intention for analyzing how the connection between geopolitics and law can assure the effectiveness of Constitutional Text and the applicable infraconstitutional legislation. The issue of whether there is sufficient normative latitude in the Constitution to respond to the challenges presented by the post-modern rule of law.

Keywords: Geopolitics. National Development Hermeneutic. Human Rights. Metaconstitucionalism.

\section{Introdução temática}

No auge dos seus trinta anos, a interpretação da Constituição de 1988 passa por profundas transformações, devido especialmente ao cenário hermenêutico pós-positivista que a circunscreve e cuja lógica de construção professa a reaproximação entre o direito e a ética, a partir da força normativa dos princípios jurídicos.

Além disso, no início do terceiro milênio, o advento do fim da Guerra Fria e da globalização da economia deu novo impulso ao direito constitucional contemporâneo, seja pela ascensão da ordem liberal de mercado, seja pela crise do Welfare State, resultando daí o surgimento de um novo ciclo estatal, chamado de Estado Pós-moderno.

Com rigor, tal arquétipo constitucional pós-moderno ainda não se encontra plenamente delineado, mas, no entanto, já é uma realidade irrefutável que projeta, a um só tempo, a imagem dicotômica entre o triunfo do capitalismo democrático do garantismo constitucional e o declínio das 
conquistas sociais do welfarismo constitucional. Nesse sentido, Gonçal Mayos, em artigo publicado pela Revista Brasileira de Estudos Políticos (RBEP), destaca que:

Como vemos también aquí son clave las tensiones provocadas por los mencionados fenómenos-inter y la turboglobalización. Estamos en un momento en que crecen los damnificados o amenazados por el actual capitalismo cognitivo, postfordista, neoliberal y turboglobalizado que además generan una élite extractiva global (Mayos, 2015), que incluso puede ser más insolidaria que las élites extractivas nacionales (Acemoglu y Robinson, 2012). Se añade además el desmontaje de las protecciones (incluso imaginarias y simbólicas) del Estado del bienestar y del viejo Estado-nación. ${ }^{3}$

É nesse diapasão que o presente trabalho tem a finalidade de investigar as relações entre a plena efetividade dos direitos fundamentais e a formulação de uma "Grande Estratégia Nacional" de desenvolvimento sob a égide de um verdadeiro Estado Democrático de Direito. Infelizmente, no Brasil, tal tema ainda é incipiente, carecendo ser desenvolvido com a devida cientificidade.

Destarte, pretende-se contribuir para a abertura de novos espaços de reflexão científica dentro da teoria constitucioanl, fazendo-a alçar voo mais elevado em direção a um constitucionalismo estratégico, que se junta ao constitucionalismo principialista pós-positivista e ao dirigismo constitucional canotilhiano. Aliás, como bem destaca o próprio Canotilho "dir-se-ia que a Constituição dirigente está morta se o dirigismo constitucional for entendido como normativismo constitucional revolucionário capaz de, só por si, operar transformações emancipatórias". ${ }^{4}$

3 MAYOS,Gonçal. Atracción y repulsión ante la turboglobalización y los fenómenos-inter integración político-económica, interconstitucionalidad e interculturalidad. In: Revista Brasileira de Estudos Políticos, vol.115, jul./dez, 2017. Belo Horizonte: RBEP/UFMG, 2017, p. 371.

4 CANOTILHO, José Joaquim Gomes. Constituição dirigente e vinculação do 
Isto quer dizer que tanto o dirigismo constitucional quanto o constitucionalismo pós-positivista (neoconstitucionalismo) não conseguem realizar as transformações emancipatórias da Constituição, vale dizer garantir a efetividade das três dimensões de diretos fundamentais, notadamente, a garantia de vida digna para todos os cidadãos, sem pobreza e sem miséria.

É nesse diapasão que vale lembrar que a Constituição de 1988, em sessão solene do Congresso Nacional, trinta anos atrás, foi promulgada sob o signo da cidadania e marcada por avanços extraordinários no regime jurídico de proteção dos direitos fundamentais, aí incluída a proteção dos hipossuficientes. ${ }^{5}$ Consolidava-se dessarte um arquétipo constitucional brasileiro, possível e qualitativamente superior aos demais, que simbolizava, ao mesmo tempo, a negação do arbítrio estatal e a ascensão exegética dos valores axiológicos compartilhados pela sociedade aberta de intérpretes da Constituição, tal qual vislumbrada por Peter Häberle. ${ }^{6}$

Dessa forma, nascia o Estado de Direito brasileiro ancorado na premissa de que o povo deve ser capaz de governar-se por si mesmo, o que evidentemente projetava o exercício pleno da cidadania como ideia fundante da Constituição de 1988, daí sua designação de Constituição Cidadã. ${ }^{7}$

legislador: contributo para a compreensão das normas programáticas. 2.ed., Coimbra: Coimbra Editora, 2001, p. XXIX, prefácio.

5 A promulgação da Constituição, em 1988, operou a transição do regime militar para o regime democrático, gestando a expansão do Estado Democrático de Direito a partir de um dinâmico processo de limitação do poder estatal, capitaneado pelo princípio da separação de poderes e pelo respeito ao catálogo de direitos fundamentais do homem comum, que se coloca acima do próprio Estado.

6 HÄBERLE, Peter. Hermenêutica constitucional. A sociedade aberta dos intérpretes da Constituição: contribuição para a inter pretação pluralista e 'procedimental' da Constituição. Tradução de Gilmar Ferreira Mendes. Porto Alegre: Sergio Antonio Fabris, 1997.

7 Talvez por ironia do destino, a promulgação do documento mais reluzente 
Partindo-se do pressuposto de que a Constituição deriva da ideia de organização suprema do Estado, no sentido de "ato de constituir o Estado", isto é, "ato de criar um novo Estado", nascia um novo Estado brasileiro, totalmente distinto de todos os seus antecessores. ${ }^{8}$ É claro que não existe um "constitucionalismo universal", válido para todos os Estados nacionais. ${ }^{9}$

Ao contrário, cada Constituição é consequência de um movimento revolucionário próprio decorrente de valores axiológicos compartilhados pela comunidade e que imprimem sua identidade nacional. No nosso caso, a ideia de Constituição Cidadã projeta-se como instrumento garantidor de todas as três grandes dimensões dos direitos fundamentais do homem brasílico.

Com efeito, não há como deixar de celebrar a dimensão protetiva da Constituição de 1988, que até aqui vem mantendo firme a jusfundamentalidade material das normas constitucionais garantidoras de direitos fundamentais, independentemente de sua dimensão ou categorização jurídico-normativa.

da história constitucional pátria, que reaproximou o Estado brasileira da sua plural sociedade, ocorreu em dia chuvoso, quase que impedindo a participação do povo nas históricas celebrações de nascimento da assim chamada Constituição Cidadã.

8 Com efeito, a promulgação de um novo ordenamento constitucional rompe com o Estado anterior, não havendo nenhuma necessidade de guardar valores axiológicos da situação jurídico-constitucional precedente. Muitas vezes, a nova Constituição surge exatamente em resposta a tais valores que se mostravam incompatíveis com a atual realidade da sociedade como um todo, daí a inevitabilidade da promulgação de um novo paradigma constitucional. Foi exatamente isso que ocorreu com a promulgação da Constituição de 1988.

9 Observa-se, no entanto, que existe um ponto de aproximação de todos os movimentos revolucionários de cunho democrático e que é ideia básica de limitação do poder estatal e a garantia dos direitos fundamentais. 
Realmente, não se pode negar que, nos últimos trinta anos, tal busca de efetividade dos direitos fundamentais, notadamente, dos direitos sociais de segunda dimensão, contribuiu para a superação gradual do positivismo jurídico e sua gradual substituição pelo paradigma neoconstitucionalista, resultando daí a consagração da dignidade da pessoa humana como novo eixo axiológico-hermenêutico do Estado Democrático de Direito.

Não se refuta o amplo campo de reflexões a fazer, no entanto, já é possível diagnosticar os avanços trazidos pela Constituição de 1988, que navega dentro de um cenário pós-tudo, vale dizer um mundo que é, a um só tempo, filosoficamente pós-moderno, juridicamente pós-positivista, midiaticamente pós-verdadeiro, soberanamente pós-nacional, geopoliticamente pós-bipolar, internacionalmente pós-americano, jusprotetivament pós-constitucional e estadisticamente pós-welfarista.

Em consequência, fácil é perceber os grandes desafios que se apresentam ao constitucionalismo brasileiro do tempo presente, cuja solução perpassa pela construção de uma hermenêutica do desenvolvimento nacional, garantidora da plena efetividade dos direitos fundamentais, notadamente, dos direitos sociais de segunda dimensão, que dependem de uma ação positiva e estratégica do Estado.

Eis aqui o núcleo duro da reflexão cientifica que se pretende desenvolver, qual seja: a necessidade de efetuar estudo trans e multidisciplinar envolvendo a teoria constitucional (direito) e a teoria das relações internacionais (geopolítica).

E é exatamente por isso que a metodologia empregada neste artigo possui uma perspectiva hermenêutica, que vai procurar investigar os diálogos epistemológicos entre a interpretação da Constituição, a eficácia dos direitos fundamentais, a elaboração da Grande Estratégia Nacional e a 
consecução dos objetivos fundamentais previstos na Constituição de 1988, no seu artigo $3^{\circ}$, incisos I a IV.

Em consequência, o método de trabalho é o hipotético-dedutivo, baseado em pesquisa bibliográfica nacional e estrangeira, que investiga, de um lado, os avanços hermenêuticos advindos da escola neoconstitucionalista do direito e, do outro, as implicações de um cenário internacional hipercomplexo, que, em curtíssimo espaço de tempo, já vivenciou dois grandes momentos de ruptura paradigmática da história da humanidade (a queda do Muro de Berlin de 1989 e o ataque às Torres Gêmeas de 2001).

Deste modo, com espeque no pensamento neoconstitucionalista pós-positivista, urge estabelecer o encontro epistemológico entre a formulação de uma Grande Estratégia Nacional de desenvolvimento econômico e social, a efetividade dos direitos fundamentais e a infranqueabilidade do Estado Democrático de Direito. ${ }^{10}$ Com isso é possível incorporar, na equação jurídica, a dimensão estratégica do Estado, o que logicamente pode gestar grandes avanços na teoria da efetividade dos direitos fundamentais, com ganhos substantivos para o exercício da plena cidadania brasileira, sob o auspício do princípio da dignidade da pessoa humana.

Por conseguinte, outro caminho científico não se terá senão o de trilhar as bases teóricas do neoconstitucionalismo, de modo a fixar, como núcleo fundante do Estado Democrático Direito, a consecução dos objetivos fundamentais

10 Assim sendo, aspira-se o desenvolvimento de um método hermenêutico destinado à interpretação da Constituição a partir dos objetivos fundamentais previstos no artigo terceiro da Constituição de 1988 e cujo objetivo é expandir a aplicabilidade pelo Poder Judiciário dos elementos geopolíticos que circunscrevem a situação jurídica do caso concreto, valendo, pois, destacar que o ineditismo dessa temática no Brasil justifica a inexistência de casos reais, que pudessem respaldar o presente estudo. No entanto, tal escassez fática não inviabiliza o desenvolvimento teórico dessa matéria. 
insculpidos no texto constitucional. ${ }^{11}$ Observe, com atenção, que, dentre os objetivos fundamentais do Estado brasileiro, encontra-se a garantia do desenvolvimento nacional.

Portanto, não se trata de mera questão estratégica, mas, principalmente, de um comando jurídico com a mesma dignidade normativa das outras normas constitucionais. Isto quer dizer que não basta reaproximar a ética e o direito, como o faz brilhantemente o paradigma neoconstitucionalista do direito; é preciso transpor limites para alcançar a plena sintonia entre geopolítica e direito, de modo a criar as bases teóricas do consequencialismo jurídico-estratégico das decisões judiciais, mormente em países de modernidade tardia, como é o caso do Brasil.

É razoável afirmar, nesse contexto dogmático, que a incompreensão do jogo estratégico mundial pode significar a redução de direitos sociais e trabalhistas das classes menos favorecidas, seja pela desindustrialização do País, seja pela subordinação a interesses externos. É nesse sentido que se sugere o aperfeiçoamento de uma hermenêutica do desenvolvimento nacional, que leve em consideração a questão estratégica no processo de ponderação de valores constitucionais.

Com efeito, um país sem estratégia de desenvolvimento nacional, é um país à deriva que, sem rumo, não sabe aonde quer chegar. Em consequência, importa considerar os seguintes questionamentos:

a) é possível construir uma sociedade livre, justa e solidária sem uma estratégia de industrialização do

11 Que são, nos termos do art. 30, incisos I a IV, da CRFB/88: construir uma sociedade livre, justa e solidária; garantir o desenvolvimento nacional; erradicar a pobreza e a marginalização e reduzir as desigualdades sociais e regionais e promover o bem de todos, sem preconceitos de origem, raça, sexo, cor, idade e quaisquer outras formas de discriminação. 
País genuinamente nacional, focada na distribuição de renda?

b) é possível garantir o desenvolvimento nacional sem a concepção de um grande projeto estratégico de Estado e, não, meros projetos de governo de determinada classe política, preocupada tão somente com a manutenção do seu poder político?

c) é possível erradicar a pobreza e a marginalização, bem como a redução das desigualdades sociais e regionais, sem a adoção de estratégias nacionais de cunho afirmativo, tratando desigualmente os desiguais na medida da sua desigualdade, deixando tal responsabilidade a cargo das regras do mercado internacional?

d) é possível promover o bem de todos, aí incluídos os direitos sociais dos hipossuficientes, adotando-se uma estratégia de subordinação aos interesses vitais dos centros mundiais de poder?

Com tal tipo de intelecção em mente, fica mais fácil compreender o método de trabalho hipotético-dedutivo do presente artigo, cuja base é a pesquisa bibliográfica focada nos grandes desafios que se apresentam à elaboração de uma hermenêutica do desenvolvimento nacional à luz do Estado Democrático de Direito.

Para tanto, será necessário investigar dois grandes eixos temáticos, a saber:

a) a hermenêutica do desenvolvimento nacional que se apresenta como a última fronteira cientifica do neoconstitucionalismo; e

b) a ideia de Constituição Estratégica, cujo diferencial é a sistematização da busca de efetividade de direitos fundamentais a partir de ações estratégicas do 
Estado, dentro de um contexto de judicialização da geopolítica.

É urgente, pois, construir um novo paradigma constitucional, com latitude científica capaz de harmonizar os direitos negativos de defesa do constitucionalismo liberal e os direitos estatais prestacionais do constitucionalismo welfarista, ao mesmo tempo em que fortalece o núcleo estratégico da industrialização do País. Eis aqui o espectro temático deste artigo.

\section{A hermenêutica do desenvolvimento nacional como última fronteira científica do neocons- titucionalismo}

O objetivo dessa segmentação temática é apresentar a hermenêutica do desenvolvimento nacional como um dos elementos fundantes do neoconstitucionalismo pós-positivista, cujo eixo central é a busca da dignidade da pessoa humana e a proteção das três grandes dimensões dos direitos fundamentais. ${ }^{12}$

Realmente, a grande característica desses trinta anos da Constituição de 1988 é a predominância do neoconstitucionalismo pós-positivista, que surge com o declínio da visão positivista de aplicação mecânica da lei. É nesse diapasão

12 Isso significa dizer que a construção de um verdadeiro Estado Democrático de Direito, cujo eixo central é a garantia de vida digna para todos os cidadãos, perpassa necessariamente pela capacidade de a elite brasileira conceber uma sofisticada estratégia nacional de desenvolvimento, sem influência de centros difusores da estrutura mundial de poder. Com efeito, num país como o Brasil, de industrialização retardada, não haverá exercício pleno da cidadania se não houver desenvolvimento nacional, se não houver a concepção de uma "Grande Estratégia Nacional", autônoma e voltada para a consecução dos objetivos fundamentais da Constituição de 1988. 
que novos elementos hermenêuticos foram paulatinamente sendo concebidos dentro de um modelo que busca se aproximar da ética a partir de exegese mais ampla que vislumbra a Constituição como um sistema aberto de regras e princípios, como bem destaca Lenio Streck:

O neoconstitucionalismo - por tudo o que ele representa - efetivamente transformou-se em um campo extremamente fértil para o surgimento das mais diversas teorias (que se pretendem) capazes de responder às demandas desse novo paradigma juspolítico-filosófico. Das teorias do discurso à fenomenologia hermenêutica, passando pelas teorias realistas, os últimos cinquenta anos viram florescer teses com objetivos comuns no campo jurídico: superar a concepção do direito entendido como um modelo de regras; resolver o problema da incompletude das regras; solucionar os casos difíceis (não 'abarcados' pelas regras) e a (in)efetividade dos textos constitucionais, nitidamente compromissórios e principiológicos, comprometidos com as transformações sociais. ${ }^{13}$ (grifos nossos)

Dessarte, na maturidade dos seus trinta anos de existência, um dos grandes desafios da Constituição de 1988 continua sendo o de construir um arquétipo hermenêutico capaz de reaproximar o direito da ética com espeque na legitimação democrática do ativismo judicial garantidor da efetividade dos princípios constitucionais, notadamente aqueles relativos aos direitos fundamentais de segunda dimensão, cuja eficácia social demanda prestações estatais. ${ }^{14}$

É nesse sentido que se afirma que a Constituição de 1988, no auge dos seus trinta anos, vive as experiências do

13 STRECK, Lenio. A resposta hermenêutica à discricionariedade positivista em tempos de pós-positivismo. In: DIMOULIS, Dimitri; DUARTE, Écio Oto. Teoria do direito neoconstitucional: superação ou reconstrução do positivismo jurídico? São Paulo: Método, 2008. p. 285.

14 Nessa tarefa, o neoconstitucionalismo pós-positivista não pode descambar para o mero decisionismo judicial, caracterizado pelas posturas discricionárias do juiz solipsista, que decide de acordo com sua précompreensão. 
assim chamado constitucionalismo da pós-modernidade, vale explicitar, o direito constitucional que nasce com o fim da Guerra Fria e com a ascensão do fenômeno da globalização da economia.

Em consequência disso, surge um desenho constitucional pré-weimariano, de cunho liberal-garantista de desconstrução do Estado Democrático Social de Direito, que se afasta do projeto epistemológico metaconstitucional orientado pelo Estado Universal de Direito, de inspiração kantiana. ${ }^{15}$

Observe, com atenção, que tal cenário acaba operando a quebra de equilíbrio do sistema jurídico de proteção dos direitos humanos, na medida em que passa a privilegiar a primeira dimensão (direitos civis e políticos de natureza absenteísta) em detrimento da segunda (direitos sociais, econômicos, culturais e trabalhistas de natureza prestacional), fazendo ressurgir das cinzas a hegemonia exegética do arquétipo constitucional liberal. ${ }^{16}$

15 Com efeito, em tempos de estatalidade pós-moderna, surge um esforço de desconstrução do dirigismo constitucional, com o desiderato de retomar o arquétipo constitucional pré-weimariano de cunho neoliberal. Realmente, com o fim da Guerra Fria, surge a tendência de adoção desse modelo pré-weimariano, vale explicitar, o modelo liberal que existia antes da Constituição de Weimar, de 1919, na Alemanha, símbolo da democracia welfarista. Isto significa dizer, por outras palavras, que o perfil constitucional que se impôs em escala planetária não foi o do projeto epistemológico metaconstitucional, baseado no Estado Universal de Direito, mas, sim, o projeto epistemológico neoliberal, baseado no Estado Garantista de Direito. Como bem destaca Vicente Barretto; “o sistema ideal a ser instrumentalizado através do livre mercado global, como seu mecanismo, é contraditória, pois pretende transferir para o âmbito universal uma forma nacional, no caso o modelo norte-americano, de ordem política e sistema econômico. (...) Nesse quadro é que se torna necessário avaliar a função da ideia de sociedade cosmopolita, de cidadania cosmopolita e de direito cosmopolítico". BARRETTO, Vicente de Paulo. O fetiche dos direitos humanos e outros temas. Rio de Janeiro: Lumen Juris, 2010, p. 223.

16 Realmente, resta indubitável que o projeto epistemológico neoliberal abarca um plexo de conceitos que se imbricam de tal ordem que acabam desaguando na universalização dos valores ocidentais, vitória do capitalismo financeiro, 
Tudo isso projeta a concepção de uma ordem política que coloca em risco as conquistas sociais a partir da neutralização axiológica da Constituição Dirigente. No dizer de Alexandre Castro Coura e Quenya Correa de Paula, em artigo publicado na Revista Brasileira de Estudos Políticos, tem-se:

À luz da compreensão como existencial e sob a ascendência da fenomenologia heideggeriana, o dirigismo constitucional, ainda que acossado pela capacidade regulatória da economia-mundo e pelas redes informais do capitalismo financeiro, tem espaço ao projeto traçado pelo poder fundador, a partir da pulsão em efetivar mudanças, cujo significado se redimensiona com a constitucionalização do Direito.(...) No constitucionalismo diretivo-programático, diferenciado pelo propósito de realizar o núcleo essencial-fundamental traçado no processo constituinte, a refundação do Direito é pautada pelo caráter finalístico voltado à alteridade e à solidariedade social, de modo que todos devem agir visando à concretização dos direitos de espectro ampliado, provenientes de uma Carta prolixa, que deixou de encampar o traçado de linhas apenas estruturais e ligadas à função de estatuto organizatório para abarcar princípios, valores e normas disciplinadoras da esfera econômica e social, algo como um plano normativo para o futuro e que leva ao Direito o debate moral. (grifos nossos) $^{17}$

De todas essas análises complexas que surgem a partir de um mosaico cientificamente multinucleado, cuja abordagem percorre desde a desconstrução do Welfare State,

neutralização axiológica da Constituição Dirigente, abertura mundial do comércio, desconstrução dos direitos sociais e trabalhistas, primazia da autonomia privada em detrimento da proteção de hipossuficientes, redução jurídica do Estado, modelos de estatalidade mínima nos campos da economia e da geopolítica, relativização do conceito de soberania, desterritorialização, constitucionalismo pré-weimariano etc.

17 COURA, Alexandre Castro, PAULA, Quenya Correa de. Ativismo judicial e judicialização da política: sobre o substancialismo e procedimentalismo no Estado Democrático de Direito. In: Revista Brasileira de Estudos Políticos, vol.116, jan./jun. 2018. Belo Horizonte: RBEP/UFMG, 2018, p. 66. 
perpassa pela evolução do regime jurídico de proteção dos direitos humanos, até, finalmente, chegar à atrição de duas grandes tendências constitucionais contemporâneas, que coloca, de um lado, o projeto epistemológico neoliberal do capitalismo democrático, liderado pelo poder geopolítico unipolar (democracia liberal de inspiração lockeana), e, do outro, a perspectiva de um projeto epistemológico metaconstitucional da ordem mundial multipolar de equilíbrio de poder (democracia cosmopolita de inspiração kantiana). ${ }^{18}$

Desta forma, nunca é demais lembrar a evolução que a teoria dos direitos fundamentais vem sofrendo ao longo da História, mormente nesta era de estatalidade pós-moderna, período no qual se concentrarão nossas principais perscrutações jurídico-constitucionais e cuja pluralidade de sentidos foi muito bem capturada por Luís Roberto Barroso, valendo, pois, reproduzir suas palavras, in verbis:

Planeta Terra. Início do século XXI. Ainda sem contato com outros mundos habitados. Entre luz e sombra, descortina-se a pós-modernidade. $\mathrm{O}$ rótulo genérico abriga a mistura de estilos, a descrença no poder absoluto da razão, o desprestígio do Estado. A era da velocidade. A imagem acima do conteúdo. O efêmero e o volátil parecem derrotar o permanente e o essencial. Vive-se a angústia do que não pôde ser e a perplexidade de um tempo sem verdades seguras. Uma época aparentemente pós-tudo: pós-

18 É nesse sentido que se busca articular estudos referentes ao panorama geopolítico mundial e seus impactos na ordem constitucional dos Estados nacionais. De fato, um dos grandes desafios do constitucionalismo da pós-modernidade é a criação de um novo regime jurídico de proteção dos direitos humanos, que caminha entre duas grandes perspectivas que se contrapõem entre si, quais sejam: de um lado, o projeto globalizante do Estado Neoliberal de Direito e, do outro, o projeto epistemológico do Metaconstitucionalismo do Estado Universal de Direito. Com tal tipo de visão, é possível compreender a correlação entre a geopolítica unipolar de poder da Pax Americana e o Estado Neoliberal de Direito, bem como a conexão entre a geopolítica multipolar de poder e o Estado Metaconstitucional de Direito. 
-marxista, pós-kelseniana, pós-freudiana. ${ }^{19}$

Com a devida agudeza de espírito, o estimado leitor haverá de concordar que o conceito de pós-modernidade é cercado por um plexo quase indecifrável de significados, não sendo, por conseguinte, objetivo desse artigo enfrentar diretamente tal questão. Nossa proposta limitar-se-á a estudar as transformações do regime jurídico de proteção dos direitos humanos nesta era de estatalidade pós-moderna e seus impactos na imposição de uma hermenêutica do desenvolvimento nacional. ${ }^{20}$

É nesse diapasão que a maestria reflexiva do Professor Antônio Celso Alves Pereira deixa claro as transformações sociais, políticas e econômicas que informam a sociedade internacional nesses tempos pós-modernos:

Do exposto, resta claramente entendido que, diante de tão profundas transformações sociais, políticas e econômicas, e, sobretudo, da velocidade com que os acontecimentos históricos se sucedem, vivemos, na pós-modernidade, uma integração cultural sem precedentes na história da humanidade. Essas realidades vieram

19 BARROSO, Luís Roberto. Fundamentos Teóricos e Filosóficos do Novo Direito Constitucional Brasileiro (Pós-modernidade, teoria crítica e póspositivismo). In: A nova interpretação constitucional. Ponderação, Direitos fundamentais e Relações Privadas. Organizador Luís Roberto Barroso. São Paulo-Rio de Janeiro: Renovar, 2003, p. 2.

20 Em termos simples, pode-se sintetizar a condição pós-moderna de acordo com as seguintes características: (i) no campo da evolução social do Estado, representa a passagem do Welfare State para o assim chamado Estado PósSocial; (ii) no plano internacional, simboliza a mudança da ordem geopolítica bipolar para uma ordem mundial ainda disputada por duas grandes correntes: de um lado, a unipolaridade da pax americana com predominância cêntrica das nações mais desenvolvidas (EUA, União Europeia e Japão) e, do outro, a multipolaridade de escopo global com crescente equilíbrio de poder de potências globais e regionais, aí incluída a ascensão geopolítica da China; e, finalmente, (iii) na esfera do direito, retrata o colapso do positivismo jurídico (império da letra da lei), despontando em seu lugar o neoconstitucionalismo (interpretação jurídica que reaproxima ética e direito). 
acelerar o curso das mudanças que, desde o fim da Primeira Guerra Mundial, vêm repercutindo nas estruturas jurídicas internacionais. Como sabemos, o Direito Internacional Público, visto como um conjunto de normas e de instituições que têm como objeto reger a vida internacional, construir a paz, promover o desenvolvimento, em suma, buscar a realização e a dignidade do gênero humano, deve prosseguir em seu processo evolutivo, funcionar efetivamente como instrumento das mudanças que se operam de forma acelerada na sociedade internacional pós-moderna. (grifos nossos) ${ }^{21}$

Desta visão pós-moderna da sociedade internacional, impende extrair a visão de construção da paz mundial, integração cultural dos povos, promoção do desenvolvimento das nações periféricas e sacralização do princípio da dignidade da pessoa humana como novo eixo axiológico da estatalidade pós-moderna.

Isto significa dizer, por outras palavras, que, nesses seus trinta anos de existencia, a Constituição de 1988 é agora vislumbrada como um sistema aberto de regras e princípios e principal fonte de aplicação do direito (filtragem constitucional). Observe que trinta anos após a promulgação da Constituição de 1988, a dogmática jurídica brasileira ganhou novos contornos científicos focados na reaproximação entre o direito e a ética a partir da efetividade dos princípios constitucionais. ${ }^{22}$

21 PEREIRA, Antônio Celso Alves. "Soberania e pós-modernidade" In: O Brasil $e$ os novos desafios do direito Internacional. BRANT, Leonardo N. Caldeira, organizador. Rio de Janeiro: Forense, 2004, p. 621.

22 Luís Roberto Barroso ensina que: A dogmática jurídica brasileira sofreu, nos últimos anos, o impacto de um conjunto novo e denso de ideias, identificadas sob o rotulo genérico de pós-positivismo ou principialismo. Trata-se de um esforço de superação do legalismo estrito, característico do positivismo normativista, sem recorrer às categorias metafísicas do jusnaturalismo. Nele se incluem a atribuição de normatividade aos princípios e a definição de suas relações com valores e regras; a reabilitação da argumentação jurídica; a formação de uma nova hermenêutica constitucional; e o 
E mais: é o neoconstitucionalismo que dá nova feição para a teoria da eficácia das normas constitucionais, notadamente dos direitos fundamentais de segunda dimensão. Na verdade, o que se constata é o esforço de superação do positivismo jurídico de aplicação silogístico-subsuntiva, buscando-se atribuir força normativa aos princípios constitucionais, que predominam no catálogo de direitos fundamentais do cidadão brasileiro comum. De fato, no neoconstitucionalismo, a efetividade dos princípios constitucionais vem sendo consolidada mediante harmonização entre o texto da lei e o sentimento constitucional de justiça. ${ }^{23}$

Eis aqui um dos grandes desafios do neoconstitucionalismo quando pensado à luz da hermenêutica do desenvolvimento nacional, qual seja: demonstrar que a efetividade dos direitos fundamentais do cidadão comum e, em especial, dos hipossuficientes, depende da postura estratégica do Estado perante o sistema internacional. Neste mister precípuo, o estudioso do direito constitucional hodierno, haverá, então, de refletir acerca da influência da geopolítica mundial sobre o ordenamento jurídico de seu Estado.

Em decorrência, sem recorrer aos elementos metafísicos das escolas do direito natural, o neoconstitucionalismo precisa repensar sua base hermenêutico-científica a partir da incorporação do princípio constitucional do desenvolvimento nacional, insculpido no artigo $3^{\circ}$, inciso II, da CRFB/ 88 .

É nesse sentido que o trabalho ora apresentado é uma

desenvolvimento de uma teoria dos direitos fundamentais edificada sob a ideia de dignidade da pessoa. Cf. Prefácio de Luís Roberto Barroso sob o subtítulo Neoconstitucionalismo, interpretação constitucional e judicialização das relações sociais no Brasil. In: BARCELLOS, Ana Paula de. Ponderação, racionalidade e atividade jurisdicional. Rio de Janeiro: Renovar, 2005.

23 GÓES, Guilherme Sandoval. Neoconstitucionalismo e dogmática póspositivista. In: A reconstrução democrática do direito público no Brasil. Organizador Luís Roberto Barroso. Renovar, 2007, p. 113. 
tentativa de fornecer subsídios para a construção de uma nova hermenêutica, que parte da eficácia normativa dos objetivos fundamentais, na mesma proporção dos demais valores constitucionalmente protegidos. Ou seja, aspira-se criar um paradigma constitucional, no qual as atividades cotidianas de juízes e tribunais levem em consideração a aplicabilidade direta desses objetivos fundamentais do Estado brasileiro, independentemente de legislação infraconstitucional superveniente.

Isto quer dizer, por outras palavras, que, para tornar aplicáveis os objetivos fundamentais previstos no artigo terceiro da Constituição de 1988, deve o Poder Judiciário fazer uso das técnicas neoconstitucionalistas que viabilizam o processo de ponderação de valores de normas de mesma dignidade constitucional, bem como do ativismo judicial proporcional, focado na garantia de direitos fundamentais. Com rigor, pode-se afirmar que a efetividade dos objetivos fundamentais do Estado brasileiro está umbilicalmente atrelada à efetividade dos direitos sociais de segunda dimensão, que, por sua vez, depende de ações estratégicas do Estado.

É por isso que a nova fronteira epistemológica do neoconstitucionalismo deve se mover no sentido de garantir o núcleo essencial do princípio constitucional do desenvolvimento nacional. Com rigor, a correção normativa do direito não pode mais desconsiderar a situação do País perante a ordem geopolítica mundial. Nesse sentido, há que se reconhecer que o direito constitucional dos países subdesenvolvidos não pode ser aquilo que o capitalismo democrático imposto pelas nações desenvolvidas diz que é.

Portanto, sob a ótica de um neoconstitucionalismo dito estratégico, a correção normativa do direito constitucional não se atrela apenas à interpretação dada ao texto positivado pelo legislador democrático de direito interno, mas, vai mui- 
to além, atingindo a esfera internacional do jogo concertado de poder em escala planetária.

Um verdadeiro Estado Democrático de Direito será aquele no qual a interpretação da Constituição não fica adstrita tão somente ao esquema imposto pelas forças hegemônicas do sistema internacional, mas, deve, sim, navegar na direção de uma geopolítica autóctone, amparada pelas teses pós-positivistas que promovem o desenvolvimento nacional a partir da técnica da ponderação de valores constitucionais.

Nesse sentido, pode-se mesmo afirmar que a efetividade ou eficácia social dos direitos fundamentais do homem brasileiro é muito mais uma questão estratégica do que uma questão jurídica, daí a ideia-força de que a hermenêutica do desenvolvimento nacional é a última fronteira epistemológica do neoconstitucionalismo. Assim sendo, além de limitar o poder do Estado, seja pela separação de poderes, seja pela garantia de direitos fundamentais, aí incluídos os direitos das minorias, um verdadeiro Estado Democrático de Direito deve ser capaz de alavancar juridicamente uma estratégia de desenvolvimento nacional independente e voltada para os seus próprios objetivos.

Em consequência, projeta-se a imagem de uma nova vertente na teoria constitucional contemporânea e que é o constitucionalismo estratégico, cujo diferencial é a incorporação da variável geopolítica circundante do mundo globalizado neodarwinista no discurso jurídico. Em essência, a fé que anima o constitucionalismo estratégico é a busca do vínculo entre os dois pensamentos (jurídico e geopolítico), trazendo a lume a reflexão acadêmico-conceitual sobre um dos fenômenos mais significativos da pós-modernidade, qual seja a judicialização da geopolítica.

Isto significa dizer que, em seu trigésimo aniversário, a Constituição de 1988 deve transpor seu isolamento 
epistemológico, que opera o direito como um sistema-fechado-autopoiético-autônomo em relação aos demais fluxos científicos, notadamente, a geopolítica e as relações internacionais. Com efeito, a Constituição não está só, isolada do seu entorno científico, sem nenhum tipo de acoplamento multidisciplinar.

Ao revés, urge compreender o papel do neoconstitucionalismo projetando a ideia-força de autonomia geopolítica capaz de construir uma estratégia de desenvolvimento social e econômico como arma central da efetividade de direitos fundamentais dos cidadãos comuns e, em especial, dos hipossuficientes.

Não há mais espaço para o zotismo acadêmico e nem para a subserviência cega às regras impostas pelas nações desenvolvidas e sua retórica de abertura mundial do comércio, patrocinadora de maior competitividade internacional. Como já dito, a correção normativa do direito precisa incorporar à teoria constitucional contemporânea a dimensão estratégica das decisões judiciais, abrindo espaço para o princípio constitucional do desenvolvimento nacional, norma constitucional tão massacrada pelos operadores do Direito dos países de modernidade tardia.

Ao contrário, de tudo se vê que a dogmática jurídica brasileira atinge novas fronteiras científicas a partir desse conjunto de ideias pós-positivistas, cujos avanços são inexoráveis e que trazem no seu bojo a concepção de um sistema constitucional aberto de regras e princípios, focado agora também na ponderação do desenvolvimento nacional com outros valores constitucionais de mesma hieraquia, como, por exemplo, a proteção do meio ambiente. Em consequência, já não se tem mais dúvidas sobre a nova hermenêutica constitucional, caracterizda pela ascensão exegética dos valores axiológicos, dentre eles a norma constitucional que 
garante o desenvolvimento nacional, cuja dignidade normativa fez com que o Poder Constituinte Originário (PCO) a qualificasse como um dos grandes objetivos fundamentais do Estado brasileiro.

De tudo se vê, por conseguinte, que a última fronteira epistemológica do neoconstitucionalismo é, induvidosamente, a incorporação da variável geopolíca à equação jurídica, isto é, a capacidade de identificar a influência das forças hegemônicas da geopolítica mundial sobre a elaboração da ordem jurídica interna.

É por tudo isso que importa desenvolver a ideia-força de Constituição Estratégica e seu papel na efetividade dos direitos fundamentais.

\section{A constituição estratégica, a efetividade dos direitos fundamentais e a judicialização da geopolítica.}

Em linhas gerais, a ideia de Constituição Estratégica pressupõe o mapeamento conceitual acerca do fenômeno da judicialização da geopolítica, no qual as grandes questões estratégicas do Estado serão levadas para a apreciação do Poder Judiciário.

Com efeito, em tempos de neutralização axiológica da Constituição Dirigente e da sacralização da ordem neodarwinista de mercado, a garantia da efetividade dos direitos fundamentais de segunda dimensão fica na dependência de uma geopolítica autônoma, focada nos interesses vitais do Estado.

Fica claro, pois, que a Constituição Estratégica deriva da visão multidimensional de organização do Estado, no sentido de "ato de constituir a ação estratégica do Estado", 
o que evidentemente mostra que a Constituição deve ser lida com filtro estratégico, capaz de compreender a influência dos fatores reais de poder não apenas no campo interno, tal qual a célebre tese de Ferdinand Lassalle, de 1862, mas, principalmente, dos fatores reais de poder hegemônico no plano da geopolítica mundial.

No âmbito do conceito de constituição em sentido sociológico de Ferdinand Lassalle, tem-se que:

Os problemas constitucionais não são problemas de direito, mas do poder: a verdadeira Constituição de um país somente tem por base os fatores reais e efetivos do poder que naquele país vigem e as constituições escritas não têm valor nem são duráveis a não ser que exprimam fielmente os fatores do poder que imperam na realidade social: eis aí os critérios fundamentais que devemos sempre lembrar. ${ }^{24}$

Ora, proposições como essa de Ferdinand Lassalle demonstram que os textos constitucionais podem se transformar em mera "folha de papel", sem nenhum valor normativo e chamada à ação tão somente quando consoante aos fatores reais de poder.

É como se a Constituição jurídica, escrita, legislada, somente integrasse o direito num "segundo nível", que viria à tona em casos que favorecessem a força ativa da sociedade. E, o que é mais interessante: os problemas constitucionais não seriam problemas de direito, mas, sim, problemas do poder. Não há como fugir disso. Daí ser possível dizer que a verdadeira Constituição de um país somente tem por base os fatores reais e efetivos do poder que vigem naquele país. ${ }^{25}$

24 LASSALLE, Ferdinand. A essência da constituição. 2ed. Rio de Janeiro: Liber Juris, 1988, p. 49.

25 Pode-se usar como exemplo dessa visão lassalleana de mera folha de papel, a Constituição de 1988, que traz no seu texto escrito o princípio do desenvolvimento nacional, cuja eficácia positiva ou simétrica é praticamente nula, diante do que se verifica na prática do mundo jurídico brasileiro. Tal 
Tal conceito de constituição pensada por Lassalle não consegue escapar de críticas advindas da reconstrução neoconstitucionalista do direito, na medida em que não se reconhece a Constituição de um determinado Estado nacional como mera folha de papel, cuja eficácia social só será alcançada quando refletir e espelhar fielmente os fatores reais de poder que imperam na realidade social.

Com efeito, a essência de uma Constituição deve superar essa imagem lassalleana de dependência dos fatores reais de poder, seja no campo interno, seja na esfera internacional, daí a relevância da força normativa da Constituição, tal qual professada por Konrad Hesse.

Em linhas gerais, o conceito normativo de Konrad Hesse defende que toda e qualquer norma constitucional deve ter garantida a sua "pretensão de eficácia", simbolizando, pois, sua força normativa. Ou seja, para Hesse, ${ }^{26}$ tal pretensão de eficácia surge com a situação de que o que ela regula seja efetivamente concretizada na realidade do mundo dos fatos.

Em suma, fácil é perceber as diferenças entre as concepções de Lassale e Hesse; a primeira desconsidera a juridicidade da Constituição, subordinando-a ao poder de fato, enquanto que a segunda reconhece a força jurígena da Constituição, vale dizer sua força de dizer o direito do Estado. ${ }^{27}$

inobservância do princípio do desenvolvimento nacional tem consequências diretas no que tange aos direitos e garantias fundamentais e cujo desfecho é a fixação progressiva do estado de miserabilidade para parcelas cada vez maiores da sociedade brasileira.

26 HESSE, Konrad. A força normativa da constituição. Porto Alegre: Sérgio Antônio Fabris, 1991, p. 14-15.

27 Observe, com a devida agudeza de espírito, que Ferdinand Lassale se ocupa tão somente da dimensão FATO, dentro da teoria tridimensional de Miguel Reale, deixando de considerar a dimensão axiológica (VALOR), bem como dimensão normativa (NORMA) e muito menos ainda a dimensão estratégica (PLANO ESTRATÉGICO). 
Realmente, o modelo constitucional de Lassale não se pauta na supremacia da Constituição escrita, mas, sim, na Constituição real concebida e engendrada pelos fatores reais de poder, isto é, pelos detentores do poder político, social, econômico e militar. Totalmente diferente é a construção teórica de Konrad Hesse e seu método hermenêutico-concretizador, cuja lógica de construção opta pela força normativa da Constituição a partir da criação de direito pelo Poder Judiciário nos casos de omissão legislativa inconstitucional.

Com a devida agudeza de espírito, observe que a Constituição Estratégica se afasta da visão lassalleana, ao mesmo tempo em que guarda estreita relação com a imagem hesseana de "constituir a ação do Estado e dos cidadãos", "criar, limitar e estruturar o poder do Estado", "garantir direitos fundamentais do cidadão comum acima dos fatores reais de poder", "promover o desenvolvimento nacional dentro de uma sociedade democraticamente plural e organizada" e "buscar o bem comum".

Para alcançar tais objetivos, ela atua como Lei Fundamental superior a todas as demais. Logo, cabe à Constituição, na qualidade de norma ápice do ordenamento jurídico, a organização do Estado, em todas as dimensões do poder nacional (política, econômica, militar, cultural e científico-tecnológica), aí incluída a estratégia de desenvolvimento nacional. Nesse sentido de que a Constituição é o regramento jurídico dos elementos constitutivos do Estado, ensinaJosé Afonso da Silva:

consiste num sistema de normas jurídicas, escritas ou costumeiras, que regulam a forma do Estado, a forma de seu governo, o modo de aquisição e exercício do Poder, o estabelecimento de seus órgãos e os limites de sua atuação, os direitos fundamentais do homem e as suas respectivas garantias. Em síntese, a constituição é o conjunto de normas que organiza os elementos constitutivos do Estado. ${ }^{28}$

28 DA SILVA, José Afonso. Curso de direito constitucional positivo. São Paulo: 
É por isso que os principais doutrinadores, ao esboçarem a definição de Constituição, ressaltam a sua natureza multidimensional, vale explicitar, salientam os diferentes conceitos ou concepções de Constituição, cada qual iluminando um tipo específico de cosmovisão, daí os conceitos de constituição em sentido sociológico de Ferdinand Lassalle, constituição em sentido normativo de Konrad Hesse, constituição em sentido político de Carl Schmitt, constituição dúctil de Gustavo Zagrebelsky ou constituição em sentido jurídico de Hans Kelsen. ${ }^{29}$

Isto quer dizer que a definição de Constituição é, epistemologicamente, dotada de alto grau de complexidade, na medida em que a Carta Magna de um Estado estará embasada por uma ideologia, ou por uma filosofia, ou por uma estratégia de desenvolvimento nacional, ou por uma teoria política dominante; o que evidente dificulta a fixação de um conceito unitário, fechado, autopoiético, cartesiano, axiomático, de Constituição.

Ao contrário, em tempos de estatalidade pós-moderna, urge desenvolver um novo conceito de Constituição, aqui vislumbrado como Constituição Estratégica, cujo desiderato é compreender o diálogo epistemológico entre o direito e a geopolítica sob a égide do Estado Democrático de Direito.

O intuito aqui é ressaltar que a decisão judicial não pode prescindir da compreensão da geopolítica mundial e seus reflexos no campo constitucional e vice-versa. Como bem destaca Philip Bobbitt:

Malheiros, 2013, p. 37-38.

29 De fato, nos dias atuais, os tipos constitucionais se diferem em virtude das diferentes escolhas feitas por determinada sociedade, não apresentando, pois, um único modelo uniforme de Constituição. Em suma, tomada pelo sentido geral, a ideia de Constituição desponta como a organização políticojurídica de algum Estado nacional, daí sua natureza personalíssima, que se projeta sobre toda a sociedade. 
A constituição não é apenas o documento que manifesta as maneiras pelas quais determinada sociedade reconhece os direitos à família, à propriedade, à terra, à segurança pessoal, ao comércio, à etnicidade e ao compromisso religioso, e ao próprio governo: pelo contrário, as sociedades, todas elas, são constituídas de determinada forma, e essa forma é a sua constituição. Os Estados, que conduzem as relações políticas da maioria das sociedades nacionais, são também constituídos de um determinado modo, que não se limita a refletir-se em sua legislação - ele é a sua legislação. ${ }^{30}$

Com efeito, a partir do fenômeno denominado judicialização da geopolítica, que desloca o campo de atuação de juízes e tribunais para a arena das relações de poder mundial, mister se faz interligar a geopolítica e o direito.

É nesse sentido que desponta a ideia de Constituição Estratégica, focada na autonomia geopolítica do Estado, como arma para evitar a recepção de conteúdos internacionais nocivos aos objetivos fundamentais constitucionais. Nessa mesma linha de pensamento, a visão de Samuel Pinheiro Guimarães, verbis:

A norma pela norma, a ideia de que é melhor para o Brasil cooperar com o processo liderado pelas grandes potências de elaborar normas internacionais - e que ter alguma norma seria melhor do que não ter nenhuma norma internacional -, pois o Brasilé um país fraco e sujeito ao arbítrio das grandes potências, é um grave equívoco. O Brasil não deve aceitar normas internacionais que contrariem ou criem empecilhos a seus interesses fundamentais de reduzir as desigualdades, de eliminar as vulnerabilidades e de realizar seu potencial. (...) muito pior será aceitar normas internacionais, e mais tarde ter de infringi-las por absoluta necessidade - e assim vir a se tornar um Estado fora da lei (outlaw) ou renegado (rogue) e sujeito a sanções militares -, do que não aceitar com serenidade, e não participar da negociação de certas normas e esquemas inter-

30 BOBBITT, Philip. A guerra e a paz na história moderna. O impacto dos grandes conflitos e da política na formação das nações. Tradução de Cristiana de Assis Serra. Rio de Janeiro: Campus, 2003, p. 192. 
nacionais que restringem gravemente a soberania e prejudicam interesses essenciais da sociedade brasileira. ${ }^{31}$

É imperioso, consequentemente, sistematizar um conceito de Constituição Estratégica, concebendo-a em sentido que revele a ligação de suas normas jurídicas com a realidade da ordem geopolítica mundial e seus fatores reais de poder dentro do sistema internacional. Com efeito, no auge dos trinta anos da Constituição de 1988, o exegeta pátrio tem o dever de examinar o constitucionalismo da pós-modernidade à luz da dimensão estratégica da Constituição e seus reflexos no desenvolvimento econômico e social do País e, na sua esteira, na proteção jurídica dos direitos fundamentais. ${ }^{32}$

Isto quer dizer que o estudioso do direito constitucional contemporâneo, independentemente de ser pós-positivista ou neopositivista, deve ser capaz de compreender os vínculos que unem o direito e a geopolítica, disciplinas que se imbricam de tal maneira que acabam desaguando na garantia de direitos fundamentais para o cidadão comum.

Infelizmente, há que reconhecer que esta linha epistemológica é ainda incipiente no Brasil. No entanto, é preciso lutar no sentido de que tal tipo de pensamento mude, notadamente, a partir da compreensão do necessário diálogo epistemológico entre a Constituição e a Estratégia Nacional, restando a esperança de que esse seja o núcleo central dos

31 GUIMARÃES, Samuel Pinheiro. Desafios brasileiros na era de gigantes. Rio de Janeiro:Contraponto,2006, p. 297.

32 Assim sendo, além dos já consagrados conceitos de constituição em sentido sociológico (Ferdinand Lassalle), constituição em sentido normativo (Konrad Hesse), constituição em sentido político (Carl Schmitt), constituição dúctil (Gustavo Zagrebelsky) e constituição em sentido jurídico (Hans Kelsen), é importante destacar, nesses trinta anos da Constituição de 1988, o conceito de constituição em sentido estratégico, cuja linhagem científica foca no desenvolvimento nacional com o meio de garantia da plena efetividade das três grandes dimensões de direitos fundamentais (direitos civis e políticos; direitos sociais e direitos coletivos e difusos). 
estudos futuros da teoria constitucional, notadamente se o Brasil conseguir materializar todo o seu potencial de desenvolvimento nacional e de industrialização.

Em tempos de globalização da economia e de estatalidade pós-moderna, intensifica-se a correspondência biunívoca entre a hermenêutica de desenvolvimento nacional e a plena efetividade de direitos fundamentais para todos os cidadãos do Estado, aí incluídos os hipossuficientes.

Na comemoração dos trinta anos da Constituição de 1988, o constitucionalista pátrio deve fomentar o pacto sinergético entre geopolítica, relações internacionais, direito internacional e direito constitucional, ${ }^{33}$ como elemento de crescimento do Estado, principalmente, quando se considera que o Brasil é um dos poucos países fora do centro mundial de poder, que já conseguiu obter certo nível de industrialização.

Infelizmente, essa noção de Constituição Estratégica ainda não se encontra consolidada no pensamento acadêmico brasileiro, o que logicamente faz com que a ordem jurídica interna recepcione normas internacionais com conteúdo estratégico prejudicial aos interesses nacionais brasileiros, impostas pelos fatores reais de poder mundial, caracterizando dessarte uma ordem mundial eivada de acordos e tratados leoninos de abertura mundial do comércio, que nada mais fazem senão agravar o ciclo de empobrecimento estatal dos países subdesenvolvidos.

33 A discussão em torno dessas relações entre geopolítica e direito se há intensificado, especialmente a partir da tentativa de reconfiguração neoliberal do Estado, cuja proposta metodológico-científica restaura o modelo de estatalidade mínima com o objetivo de desregulamentar relações jurídicas privadas, relativizando o conceito de soberania. Para grande parte da doutrina, o fim dos ciclos democráticos da modernidade (Estado liberal e Welfare State) ocorre exatamente com a queda do Muro de Berlim, símbolo do colapso do império soviético e do fim da bipolaridade geopolítica. 
Por isso, em determinadas situações, a interpretação da Constituição deve ser aberta a elementos metajurídicos que impactam diretamente a vida nacional e, em especial, a vida dos hipossuficientes, que experimentam e vivenciam as aflições de um verdadeiro quadro de inópia humana, daí a relevância científica do conceito de Constituição Estratégica.

Sem dúvidas, um dos mais importantes desafios da interpretação da Constituição de 1988 no futuro será a capacidade de identificar a influência da geopolítica mundial sobre a elaboração de normas jurídicas de direito interno, com o intuito de promover o desenvolvimento estratégico do País e, na sua esteira, consolidar a efetividade dos direitos fundamentais liberais e sociais, garantindo-se vida digna para todos a partir da igualdade de oportunidades e, não, por intermédio de ações afirmativas.

Trata-se, por conseguinte, de uma teoria material da Constituição focada em políticas públicas de desenvolvimento nacional e de promoção da dignidade da pessoa humana, com redução das desigualdades regionais e sociais.

É a própria designação "Constituição Estratégica" que já projeta por si só a ideia-força de conciliar o sentimento constitucional de justiça e o pensamento estratégico. Nesse sentido, por exemplo, o papel central de uma Constituição dita Estratégica seria buscar sistematizar o diálogo entre as leis orçamentárias, principalmente, os planos plurianuais (PPA) com os grandes projetos estratégicos de industrialização do País. ${ }^{34}$

34 Com rigor, a própria estrutura do PPA de quatro anos já mostra a falta de visão estratégica de longo prazo do legislador originário brasileiro, que não vislumbrou a possibilidade de fixação de planos estratégicos de médio ou longo prazo que ultrapassassem um determinado governo (4 anos de mandato presidencial), ou seja, não há nenhum documento orçamentário pátrio que contemple uma verdadeira política pública de Estado com prazo entre seis e oito anos. 
Aqui, o mais importante é perceber que a incidência do elemento estratégico é que vai legitimar materialmente a elaboração do orçamento público sob a égide de uma Constituição dita Estratégica. Com isso, neutraliza-se possível proposta orçamentária desvinculada do interesse estratégico nacional, que, por sua vez, se atrela, umbilicalmente, à dignidade da pessoa humana e aos objetivos fundamentais insculpidos na Carta Ápice. ${ }^{35}$

Busca-se, aqui, a compreensão da Constituição em sua totalidade, aí incluída sua dimensão estratégica, que se coloca, lado a lado, às vertentes liberal e social, bem como à inserção internacional do Brasil atrelada à busca da consolidação de uma ordem mundial multipolar, calcada no equilíbrio geopolítico de poder mundial. ${ }^{36}$

Urge, pois, introduzir na cultura jurídica brasileira o fenômeno da judicialização da geopolítica, que, em seu âmago, significa que as principais decisões geopolíticas do Brasil serão levadas ao Supremo Tribunal Federal. E mais: por mais paradoxal que possa parecer, na grande maioria das vezes, será o próprio Poder Legislativo a via que deslocará para o Poder Judiciário tais questões geopolíticas, seja no controle concentrado por meio das ações diretas de inconstitucionalidade, seja no controle preventivo por meio dos mandados de segurança impetrados por parlamentares.

$35 \mathrm{O}$ combate à corrupção encontra aqui um grande aliado, na medida em que a sociedade aberta de intérpretes da Constituição, tal qual vislumbrada por Peter Häberle, evidentemente, estará aferindo a qualidade das políticas públicas formuladas pelo Congresso Nacional, isto é, se tais políticas estão ou não de acordo com os objetivos fundamentais do Estado, ou se, apenas, guardam interesses privados escusos.

36 Seu grande mérito científico encontra-se na preocupação de avaliar se a Constituição e a Estratégia Nacional estão em consonância com os objetivos fundamentais fixados pela própria Constituição, dentro de uma ideia material de constitucionalismo estratégico-programático, que projeta fins e programas a serem alcançados no futuro pelo legislador democrático ordinário. 
Observe, com atenção, que no inicio do terceiro milênio e nesses trinta anos da Constituição de 1988, vive-se novos tempos de neoconstitucionalismo pós-positivista, nos quais predomina os fenômenos da judicialização da política e do ativismo judicial. Com efeito, em perspectiva hermenêutico-conceitual, a judicialização da geopolítica simboliza fenômeno inédito na teoria constitucional, na medida em que transpõe o patamar da simples judicialização da política.

De fato, resta indubitável que o fenômeno da judicialização da geopolítica, na verdade, transcende o âmbito da formulação interna de políticas públicas para alcançar o terreno movediço das grandes decisões estratégicas do Estado tomadas dentro de um intricado quadro de forças geopolíticas conflitantes do cenário mundial.

Passa-se, pois, da mera judicialização da política para o tão complexo fenômeno da judicialização da geopolítica.

Eis aqui o grande desafio da interpretação constitucional nesses seus trinta anos de existência: incorporar na técnica da ponderações de valores constitucionais de mesma hierarquia os princípios do desenvolvimento nacional e da soberania juntamente com as demais normas constitucionais, aí incluídos os direitos fundamentais e a proteção do meio ambiente.

Nesse sentido, os grandes projetos geopolíticos do País serão judicializados, cabendo ao Poder Judiciário, notadamente, o Supremo Tribunal federal, conhecer os valores em jogo, não podendo nesse mister desconsiderar os elementos geopolíticos que circunscrevem o cenário mundial. Para o bem ou para o mal, o STF necessita conhecer os impactos da geopolítica mundial não apenas sobre nossa Carta Ápice, mas, também, sobre o ordenamento jurídico como um todo. ${ }^{37}$

37 Isto significa dizer que o jurista/juiz do tempo presente não pode ficar alheio ao quadro geopolítico mundial, sem desvelar os impactos da globalização 
Deste modo, a decisão do juiz hodierno deve ter a preocupação de vincular os dois pensamentos (jurídico e geopolítico), não deixando, pois, de examinar a matriz de impactos cruzados que circunscreve tanto o jogo geopolítico de poder mundial, quanto a formulação dos marcos regulatórios de direito interno. ${ }^{38}$

Duas imagens daí derivam: de um lado, a imagem do magistrado neoconstitucionalista, atuando como guardião axiológico da Constituição e protetor dos direitos fundamentais sob os influxos do sentimento constitucional de justiça.

Do outro, a imagem do magistrado tradicional, formado no dogma da cientificidade pura do direito e curador da aplicação axiomático-mecânica da lei, sem nenhum contato epistemológico outras disciplinas, notadamente a geopolítica e as relações internacionais.

Isto quer dizer que o Poder Judiciário - enquanto parte integrante do poder político do Estado - se vê cada vez mais despreparado para solucionar complexos problemas brasileiros, que são levados para juízes e tribunais, independentemente da sua vontade. Ou seja, as grandes questões estratégicas do Brasil (marcos regulatórios de exploração do pré-sal; políticas de conteúdo nacional, base da indústria de defesa, dicotomia entre a proteção do meio ambiente $x$ construção de hidrelétricas na Amazônia, demarcação das terras indígenas; fusão de empresas multinacionais, como é o caso da Boeing com a Embraer e muitas outras).

da economia no plano interno da proteção dos direitos fundamentais de segunda dimensão (direitos sociais, econômicos, culturais e trabalhistas).

38 Como já dito, infelizmente a análise cientificamente séria dessa temática ainda é incipiente no Brasil e na América Latina como um todo, talvez em decorrência de uma falta de autonomia intelectual dessa região geopolítica em relação aos centros mundiais de poder. O fato é que o atual estádio epistemológico da teoria constitucional, em face do cenário contemporâneo de estatalidade pós-moderna, não pode deixar de levar em consideração a variável geopolítica no âmbito das decisões judiciais. 
É nesse sentido que o fenômeno da judicialização da geopolítica inova substancialmente a teoria constitucional hodierna com sua impactante ideia de Constituição Estratégica, com a qual o Poder Judiciário é conectado com a globalização da economia e a geopolítica mundial. Urge, por conseguinte, que a classe de constitucionalistas do Brasil ganhe intelecção mais densa para compreender que, para além das grandes questões políticas nacionais que se apresentam ao Poder Judiciário, o juiz constitucional do terceiro milênio já não pode mais ficar apartado do conteúdo geopolítico que subjaz à questão constitucional sendo por ele aferida.

Desse modo, para aplicar os princípios jurídicos que materializaram o sentimento constitucional de justiça, juízes e tribunais necessitam trilhar a senda multidisciplinar que mescla questões estratégicas e constitucionais que lhes são apresentadas para a decisão final de mérito. ${ }^{39}$

Aliás, é bem de ver que o fenômeno da judicialização da (geo)política - aqui compreendido como a invasão do direito sobre a (geo)política - já era diagnosticado desde os tempos de Alexis de Tocqueville, valendo reproduzir in verbis, fragmentos de seu pensamento que impressionam pela atualidade e clarividência:

39 Com rigor, é a força jurígena de decisões judiciais que abre caminho para a realização da Constituição dentro de um contexto eivado de visões e interesses em colisão envolvendo um amplo segmento da sociedade, tais como, representantes das empresas multinacionais, jornalistas, líderes políticos, professores universitários, empresários nacionais com interesses diretamente ligados ao tema, doutrinadores, juízes, membros do Ministério Público, defensores públicos, advogados, militares etc. Daí nasce a figura de um novo centro de poder do Estado Pós-Moderno: a intelligentzia jurídica, operadores do direito com capacidade de influir diretamente os destinos do País, seja para o bem, seja para o mal. Com efeito, é a judicialização da geopolítica que serve de base para a atuação dessa intelligentzia jurídica, uma vez que desloca para o Poder Judiciário o debate das grandes questões geopolíticas do Brasil. 
O que o estrangeiro encontra maior dificuldade em compreender nos Estados Unidos é a organização judiciária. Quase não há, por assim dizer, ocorrência política na qual não se evoque a autoridade do juiz. De onde se conclui, naturalmente, que nos Estados Unidos o juiz é uma das primeiras forças políticas. (...) Aos olhos do observador, o magistrado dá a impressão de jamais se imiscuir nos negócios públicos a não ser por acaso; só que esse acaso acontece todos os dias. (...) De onde vem esse poder? (..) Os americanos outorgaram a seus tribunais um imenso poder político (...) O juiz americano é, por conseguinte, levado ao terreno da política, independentemente de sua vontade. Ele só julga a lei porque tem de julgar um processo, e não pode eximir-se de julgar um processo. A questão política que ele deve resolver liga-se ao interesse dos pleiteantes, e não poderia recusar-se a decidi-la sem incorrer na negação da justiça. ${ }^{40}$

Verdadeiramente impressionante a lição de Alexis de Tocqueville, quando destaca que o Poder Judiciário é uma das primeiras forças políticas dos Estados Unidos, o que evidentemente faz do magistrado um dos principais decisores (geo)políticos da nação. Em consequência, por dever de ofício, ao decidir a questão político-estratégica que lhe é submetida, o juiz decide o destino do País. É cumprindo sua missão judicante que o juiz penetra na esfera (geo)política para transformar a vida nacional. ${ }^{41}$

Como bem destaca Paulo Bonavides, o intérprete ao concretizar a norma constitucional não deve desmembrá-

40 TOCQUEVILlE, Alexis de. Da democracia na América. Traduzido e condensado por José Lívio Dantas. Rio de Janeiro: Biblioteca do Exército,1998, p. 70-74.

41 De observar-se, por conseguinte, que o fenômeno da judicialização da (geo) política decorre da própria atividade jurisdicional, sendo por isso mesmo necessário que se trace um limite para sua atuação. Da mesma forma com o que ocorre com o fenômeno da judicialização da política, a invasão do direito sobre a geopolítica somente dará bons frutos quando acompanhada pela autolimitação que o juiz a si próprio deve impor-se, abrindo o espaço normativo para a vontade majoritária democraticamente respaldada. 
-la de seu manancial político e ideológico, das nascentes da vontade política fundamental. ${ }^{42}$

Enfim, com base na análise realizada, resta induvidoso que o eixo hermenêutico do constitucionalismo da pós-modernidade perpassa necessariamente pela atividade exegético-estratégica do Poder Judiciário, que se transforma, por sua vez, na última trincheira da concretização dos direitos constitucionais, notadamente, os direitos fundamentais de segunda dimensão. ${ }^{43}$

É nesse diapasão que os conceitos de Constituição Estratégica e judicialização da geopolítica se transformam na pedra angular da hermenêutica do desenvolvimento nacional, que, por sua vez, se apresenta como última fronteira epistemológica do neoconstitucionalismo pós-positivista.

42 Paulo Bonavides ensina que: As relações que a norma constitucional, pela sua natureza mesma, costuma disciplinar são de preponderante conteúdo político e social e por isso mesmo sujeitas a um influxo político considerável, senão essencial, o qual se reflete diretamente sobre a norma, bem como sobre o método interpretativo aplicável. BONAVIDES, Paulo. Curso de Direito Constitucional. $8^{\text {a }}$ ed. São Paulo: Malheiros, 1998, p. 419-420.

43 Assim, a decisão judicial - no plano do constitucionalismo estratégico - é aquilo que o juiz-intérprete desvelou ou designou dentre muitas outras alternativas exegético-estratégicas com diferentes impactos na ordem constitucional e, em casos que prejudiquem o interesse nacional, a opção deve ser pelo reconhecimento daquela que garanta os direitos fundamentais, especialmente a dignidade da pessoa humana do cidadão comum. Assim, o que se quer aqui ressaltar é o fato de que os problemas do fenômeno da judicialização da política não ocorrem apenas por força de fatores internos, e.g., disputa partidária pelo poder político, mas, também pelas tensões advindas do jogo geopolítico mundial e seu complexo quadro de desregulamentação jurídica do mercado global, juntamente, com a redução jurídica do Estado soberano. Com efeito, há que se compreender que, no plano epistemológico do constitucionalismo da pós-modernidade, as grandes questões estratégicas mundiais transcendem as fronteiras dos Estados nacionais para penetrarem no âmbito normativo de proteção dos direitos fundamentais do cidadão comum dos países de modernidade tardia. 


\section{Considerações finais}

O presente trabalho analisou as características do neoconstitucionalismo pós-positivista no auge dos trinta anos da Constituição de 1988, procurando destacar a relevância científica da hermenêutica do desenvolvimento nacional.

Destarte, em um primeiro momento, investigou-se a influência dos fatores reais de poder mundial sobre o constitucionalismo dos países de modernidade tardia, para, em seguida, destacar a necessidade de que a Constituição seja vislumbrada sob a ótica da Grande Estratégia Nacional. Neste diapasão, enfatizou-se uma imagem incomum no âmbito da teoria constitucional tradicional e que é aquela que mostra as conexões entre a geopolítica e o direito.

Com efeito, o pensamento acadêmico pátrio ainda não vislumbrou uma teoria constitucional concebida à luz do perfil dos detentores do poder, em que a realidade geopolítica mundial se perfaz como consectário do poder em si. Isto significa dizer que a Constituição não está só, ao revés, sofre influência da estrutura hegemônica de poder, como bem destaca Ives Gandra da Silva Martins:

Não sem razão, pensadores como Carl Schmitt e Maquiavel, desmascararam a política (...) demonstrando, seu viés de fantasia filosófica e cinismo pragmático. Para os referidos autores, para eles, política se justifica, fundamentalmente, à luz de seu principal personagem, a partir, exclusivamente, da ambição pelo exercício do poder. O poder, em qualquer estágio, vale por si, não sendo de sua essência - embora muitas vezes dele decorra - a prestação de serviços públicos. ${ }^{44}$

E mais adiante arremata o grande jurista pátrio, analisando as regras naturais do poder de Cálicles, "para mim,

44 MARTINS, Ives Gandra da Silva. Uma breve teoria do poder. São Paulo: Editora Revista dos Tribunais, 2009, p. 13. 
quem tem capacidade para conquistá-lo [o poder] somente respeita a lei e a ordem jurídica, na medida em que estas lhe servem, mas se tiver mais força que o estamento que comanda, modifica sua estrutura, conforme seus anseios de domínio e manutenção". ${ }^{45}$

Foi com tal espírito acadêmico que o presente artigo procurou sistematizar a nova dinâmica da teoria constitucional contemporânea, que se vê obrigada a incorporar na equação constitucional elementos geopolíticos da estrutura mundial de poder, que incidem, diretamente, seja na plena efetividade ou eficácia social dos direitos fundamentais, seja na proteção dos hipossuficientes.

Portanto, ao jurista do século XXI já não mais lhe é dado permanecer alheio a variáveis metajurídicas que influenciam diretamente o direito interno dos países de modernidade tardia. Com efeito, não há como negar que o direito constitucional hodierno perpassa por uma de suas fases mais delicadas de sua evolução, onde se constata com maior clareza o fenômeno da judicialização da geopolítica e, na sua esteira, os riscos de neutralização axiológica da Constituição Dirigente e de retrocesso nas conquistas dos direitos fundamentais de segunda dimensão.

Assim, no auge dos trinta anos da Constituição de 1988, o exegeta pátrio tem a missão de desenvolver o direito constitucional, atribuindo força normativa aos princípios jurídicos, fazendo valer o sentimento constitucional de justiça. Foi por isso que este trabalho procurou ab initio usque ad mais desenvolver a ideia de uma hermenêutica do desenvolvimento nacional como um modelo exegético pós-positivista, focado na consecução dos objetivos fundamentais do Estado brasileiro e capaz de harmonizar os direitos negativos de defesa do constitucionalismo liberal e os direitos estatais prestacionais

45 Idem, p. 22. 
do constitucionalismo welfarista, ao mesmo tempo em que fortalece o núcleo estratégico da industrialização do País.

Com efeito, a hermenêutica do desenvolvimento nacional tem a missão de idealizar um novo arquétipo constitucional de estatalidade positiva atenuada, que harmonize de um lado o binômio livre iniciativa - expansão mundial do comércio e, do outro, o trinômio dignidade da pessoa humana - desenvolvimento nacional - sentimento constitucional de justiça. ${ }^{46}$

Assim, pela sistematização engendrada, foi possível demonstrar que a hermenêutica do desenvolvimento nacional se apresenta como última fronteira científica do neoconstitucionalismo. No Brasil, infelizmente, a falta de visão estratégica dos decisores e formuladores de políticas públicas acaba refletindo na recepção de conteúdos geopolíticos externos que inexoravelmente agravam o ciclo de empobrecimento estatal, gestando dessarte o estado de miserabilidade das classes menos favorecidas, daí a relevância do conceito de Constituição Estratégica como instrumento de garantia de direitos fundamentais, especialmente os direitos sociais de segunda dimensão de cunho prestacional. ${ }^{47}$

46 E mais: o encontro jurídico-estratégico de valores liberais (livre iniciativa e estatalidade mínima) e valores sociais (justiça social e estatalidade positiva) será capaz de garantir o núcleo essencial da dignidade humana, fixando as condições materiais mínimas para o exercício pleno da cidadania do homem brasílico.

47 Realmente, como amplamente visto, é certo afirmar que a Constituição não tem apenas a função de ser a lei suprema do Estado (conceito jurídico de Constituição de Hans Kelsen), mas, desempenha, também, papel emancipatório que somente se cumpre se houver por parte do Estado ações estratégicas concretas voltadas para a consecução dos objetivos fundamentais constitucionais (conceito estratégico de Constituição). Ou seja, uma Constituição permanecerá como letra morta (mera folha de papel como quer Lassalle) enquanto a ação estratégica do Estado não for capaz de promover a consecução dos comandos constitucionais, notadamente aqueles que garantem a dignidade da pessoa humana 
Esta é a razão pela qual o legislador pátrio tem que repensar um novo paradigma estatal, ${ }^{48}$ considerando agora novas formas de relações internacionais (geopolítica multipolar) e novas fórmulas de interpretação da Constituição (neoconstitucionalismo estratégico). A solução vislumbrada terá que privilegiar a igualdade de oportunidades para todos os cidadãos brasileiros.

A questão é complexa, mas, não pode deixar de ser enfrentada pelo jurista do século XXI: é preciso compreender o novo estádio hermenêutico-conceitual do constitucionalismo da pós-modernidade, que incorpora na sua equação epistemológica a intrincada relação de forças hegemônicas, estatais e não estatais (empresas multinacionais, ONGs, etc.) com o direito constitucional.

$\mathrm{Na}$ companhia do eminente doutrinador italiano Natalino Irti, defendeu-se a tese de que o sistema internacional - impulsionado pelas forças de "des-limitação" da economia e da tecnologia - não desconhece a máxima de que o território estabelece a medida do senhorio jurídico do Estado e que por isso mesmo é fundamental saber explorar a dimensão espacial do direito. ${ }^{49}$ É nesse sentido que Ignácio Ramonet põe a nu a ideia de civilização do caos dos novos senhores do mundo (conglomerados financeiros e industriais privados), do planeta saqueado (destruição sistêmica do meio

48 Deitado em berço esplêndido, o gigante brasileiro se submete a pressões externas que só fazem agravar a exclusão social no nosso País. Urge, pois, ao Brasil, afastar postura geopolítica submissa e recuperar o tempo perdido. Dessarte, de que adianta comemorar-se a força normativa da Constituição sob a égide de uma pujante democracia, quando se constata a inaptidão do País para conceber uma Estratégia Nacional que garanta efetivamente os direitos fundamentais mínimos do cidadão comum, seu núcleo essencial de dignidade humana?

49 IRTI, Natalino. Geodireito. Tradução de Alfredo Copetti Neto e André Karan Trindade. Conferência sobre biodireito e geodireito. Universidade de São Paulo, São Paulo, 2007, p.1. 
ambiente), das metamorfoses do poder e suas formas negociadas, reticulares e horizontais (mídia, grupos de pressão e organizações não-governamentais), do choque das novas tecnologias (bem ao lado do choque de civilizações) e tudo isso fazendo exalar nessa sociedade ocidental pós-moderna um mau cheiro de remorso e algo parecido com um sentimento de náusea. ${ }^{50}$

De clareza meridiana, portanto, a clivagem jurídico-estratégica do constitucionalismo da pós-modernidade e a globalização da economia, daí a necessidade de harmonizar o garantismo constitucional liberalizante e o dirigismo constitucional welfarista. De fato, tal harmonização das vertentes liberal e social é feita a partir da ideia de Constituição Estratégica, que desloca para o epicentro do constitucionalismo democrático a questão geopolítica de poder mundial como novo imperativo categórico da pós-modernidade.

Com estas considerações encerra-se este trabalho acadêmico, na expectativa de sua contribuição para o aperfeiçoamento da teoria constitucional, na medida em que destaca que a estratégia nacional e o direito constitucional devem estar lado a lado na garantia dos direitos fundamentais do cidadão comum.

\section{Referências bibliográficas}

BARCELLOS, Ana Paula de. Ponderação, racionalidade e atividade jurisdicional. Rio de Janeiro: Renovar, 2005.

BARRETTO, Vicente de Paulo. O fetiche dos direitos humanos e outros temas. Rio de Janeiro: Lumen Juris, 2010.

BARROSO, Luís Roberto. Fundamentos Teóricos e Filosóficos do Novo Direito Constitucional Brasileiro (Pós-

50 RAMONET, Ignácio. A geopolítica do caos. Petrópolis, RJ: Vozes, 1998, p. 7-12. 
-modernidade, teoria crítica e pós-positivismo). In: A nova interpretação constitucional. Ponderação, Direitos fundamentais e Relações Privadas. Organizador Luís Roberto Barroso. São Paulo-Rio de Janeiro: Renovar, 2003.

BOBBITT, Philip. A guerra e a paz na história moderna. O impacto dos grandes conflitos e da política na formação das nações. Tradução de Cristiana de Assis Serra. Rio de Janeiro: Campus, 2003.

BOSON, Gerson de Britto Mello. A constitucionalização do direito internacional. Belo Horizonte: Del Rey, 1996.

BRASIL. Escola Superior de Guerra. Manual Básico. Volume I. Elementos doutrinários. Rio de Janeiro, 2008.

BRZEZINSKI, Zbigniew. Second chance: three presidents and the crisis of american superpower. New York: Basic Books, 2007. BULL, Hedley. A sociedade anárquica. Brasília/São Paulo: UnB/Ipri/Impr.Oficial do Estado, 2002.

CASELLA, Paulo Borba (org). Rio de janeiro: Renovar, 2000. CHOMSKY, Noam. 11 de setembro. Tradução Luiz Antonio Aguiar. $6^{\mathrm{a}}$ ed. Rio de Janeiro, Bertrand Brasil, 2002.

. Contendo a democracia. Tradução de Vera Ribeiro. Rio de Janeiro: Record, 2003.

COURA, Alexandre Castro, PAULA, Quenya Correa de. Ativismo judicial e judicialização da política: sobre o substancialismo e procedimentalismo no Estado Democrático de Direito. In: Revista Brasileira de Estudos Políticos, vol.116, jan./jun. 2018. Belo Horizonte: RBEP/UFMG, 2018.

DA SILVA, José Afonso. Curso de direito constitucional positivo. São Paulo: Malheiros, 2013.

DIMOULIS, Dimitri; DUARTE, Écio Oto. Teoria do direito neoconstitucional: superação ou reconstrução do positivismo jurídico? São Paulo: Método, 2008. 
FIORI, José Luís. O poder global e a nova geopolítica das nações. São Paulo: Boitempo Editorial, 2007.

. O mito do colapso do poder americano. Rio de janeiro: Editora Record, 2008.

FRIEDMAN, Thomas. O mundo é plano: uma breve história do século XXI. Rio de janeiro:Objetiva, 2007.

FUKUYAMA, Francis. O fim da história. Rio de Janeiro: Biblioteca do Exército, 1998.

GÓES, Guilherme Sandoval. Neoconstitucionalismo e dogmática pós-positivista. In: A reconstrução democrática do direito público no Brasil. Organizador Luís Roberto Barroso. Renovar, 2007.

GUIMARÃES, Samuel Pinheiro. Desafios brasileiros na era de gigantes. Rio de Janeiro: Contraponto, 2006.

- Quinhentos anos de periferia. 3ed. Porto Alegre/Rio de Janeiro: Ed. Universidade/UFRGS/Contraponto, 2001. HÄBERLE, Peter. Hermenêutica constitucional. A sociedade aberta dos intérpretes da Constituição: contribuição para a interpretação pluralista e 'procedimental' da Constituição. Trad. de Gilmar Ferreira Mendes. Porto Alegre: Sergio Antonio Fabris Editor, 1997.

HESSE, Konrad. A força normativa da constituição. Porto Alegre: Sérgio Antônio Fabris, 1991.

HUNTINGTON, Samuel. O choque de civilizações e a recomposição da ordem mundial. Rio de Janeiro: Biblioteca do Exército, 1998.

IRTI, Natalino. Norma e luoghi. Problemi di geo-diritto. RomaBari: Laterza, 2005.

. Geodireito. Tradução de Alfredo Copetti Neto e André 
Karan Trindade. Conferência sobre biodireito e geodireito. Universidade de São Paulo, São Paulo, 2007.

KANT, Immanuel. À paz perpétua. Porto Alegre: L\&PM, 1989.

KISSINGER, Henry. American Foreign Policy, 2. ed., Norton, Nova York, 1977.

LASSALLE, Ferdinand. A essência da constituição. 2ed. Rio de Janeiro: Liber Juris, 1988, p. 49.

MELLO, Celso D. de Albuquerque. Curso de direito internacional público, vol. I, 12a ed. Rio de Janeiro: Renovar, 2000.

. Curso de direito internacional público, vol. I, $12^{\mathrm{a}} \mathrm{ed}$. Rio de Janeiro: Renovar, 2000.

. Direito Constitucional Internacional: uma introdução. $2^{a} e d$. Rio de Janeiro: Renovar, 2000.

MORGENTHAU, Hans. Politics among nations. The struggle for power and peace. New York, Alfred A. Knopf, Inc, fifth edition, 1948.

MONIZ BANDEIRA, Luiz Alberto. Formação do império americano: da guerra contra a Espanha à guerra no Iraque. Rio de Janeiro: Civilização Brasileira, 2006.

OCAMPO, Raúl Granillo. Direito internacional público da integração. Rio de Janeiro: Elsevier, 2009.

PARET, Peter. Makers of modern strategy: from Machiavelli to the nuclear age. New Jersey: Princeton Unoiversity Press, 1986.

PECEQUILO, Cristina Soreanu. Introdução às relações internacionais. Temas, atores e visões. Petrópolis: Editora Vozes, 2005.

PEREIRA, Antônio Celso Alves. "Soberania e pós-modernidade" In: O Brasil e os novos desafios do direito Internacional. 
BRANT, Leonardo N. Caldeira, organizador. Rio de Janeiro: Forense, 2004.

RAMONET, Ignácio. A geopolítica do caos. Petrópolis, RJ: Vozes, 1998.

TESCHKE, Benno. The myth of 1648. Class, geopolitics and making of modern international relations. Londres, Nova York: Verso, 2003.

TOCQUEVILLE, Alexis de. Da democracia na América. Traduzido e condensado por José Lívio Dantas. Rio de Janeiro: Biblioteca do Exército,1998.

STRECK, Lenio. A resposta hermenêutica à discricionariedade positivista em tempos de pós-positivismo. In:

TUATHAIL, Gearóid Ó. Critical geopolitics. The politics of writing global space. Bordelines, volume 6: Minnesota, 1996, VIANNA, Luiz Werneck [et al.]. A judicialização da política e das relações sociais no Brasil. Rio de Janeiro: Revan, 1999.

WALLERSTEIN, Immanuel. Após o liberalismo. Petrópolis:Vozes, 2002.

Recebido em 04/09/2018.

Aprovado em 16/10/2019.

\section{Guilherme Sandoval Góes}

E-mail: guilherme.sandoval@terra.com.br

\section{Cleyson de Moraes Mello}

E-mail: profcleysonmello@hotmail.com 